\title{
STRATEGIC MILITARY COLONISATION: THE CAPE EASTERN FRONTIER 1806-1872
}

\author{
Linda Robson ${ }^{*}$ and Mark Oranje \\ Department of Town and Regional Planning, University of \\ Pretoria
}

\begin{abstract}
The Cape Eastern Frontier of South Africa offers a fascinating insight into British military strategy as well as colonial development. The Eastern Frontier was for over 100 years a very turbulent frontier. It was the area where the four main population groups (the Dutch, the British, the Xhosa and the Khoikhoi) met, and in many respects, key decisions taken on this frontier were seminal in the shaping of South Africa. This article seeks to analyse this frontier in a spatial manner, to analyse how British settlement patterns on the ground were influenced by strategy and policy. The time frame of the study reflects the truly imperial colonial era, from the second British occupation of the Cape colony in 1806 until representative selfgovernance of the Cape colony in 1872 .
\end{abstract}

\section{Introduction}

British colonial expansion into the Eastern Cape of Southern Africa offers a unique insight into the British method of colonisation, land acquisition and consolidation. This article seeks to analyse the British imperial approach to settlement on a turbulent frontier. The spatial development pattern is discussed in order to understand the defensive approach of the British during the period 1806 to 1872 better.

Scientia Militaria, South African Journal of Military Studies, Vol 40, Nr 2, 2012, pp. 46-71. doi: $10.5787 / 40-2-996$
South Africa began as a refuelling station for the Dutch East India Company on the lucrative Indian trade route. However, military campaigns in Europe played

\footnotetext{
* Linda Robson is a PhD student in the Department of Town and Regional Planning at the University of Pretoria, Pretoria, South Africa.

$\dagger$ Mark Oranje is professor and Head of the Department of Town and Regional Planning at the University of Pretoria, Pretoria, South Africa.
} 
themselves out in colonial political manoeuvring, and led to the Cape being taken over by the British firstly as a temporary measure with the consent of the Prince of Orange who fled Napoleon and sought refuge in England, and later by annexation. By the time the British occupied the Cape, colonial settlement had already expanded into the Eastern Cape Region. The area was settled as very-low-density cattle stock farms and the only town in the area was Graaff-Reinet (established in 1786).

Ten years after the establishment of Graaff-Reinet in 1796, Barrow described the town as

... an assemblage of mud huts placed at some distance from each other, in two lines, forming a kind of street. At the upper end stands the house of the landdrost (magistrate), built also of mud, and a few miserable hovels, that were intended as offices for the transaction of public business; most of these in so ruinous a condition as not to be habitable ...

When the British colonised the area they therefore saw it as territory with no urban settlement pattern.

This "virgin rural territory", with only the make-shift town of Graaff-Reinet as hub, would soon become the area in which the class, racial and cultural prejudices of the British colonial authorities were to be played out. Not only would it experience a period of one hundred years of intermittent warfare, it also saw class struggles (particularly within the British settler groups, especially after the arrival of skilled artisans), struggles for land between different agricultural societies (the Dutch and the Xhosa) and struggles between owners of different types of commercial agricultural estates (the British). In addition, there were also vast differences in public opinion, from the liberal humanitarian missionary attitude to the commercial and imperial British colonial government's view, and the Dutch farmers' attitude that they were the chosen race. Also the Xhosa had tensions between various tribal groupings. ${ }^{3}$

The area historically stretches from the Sundays River in the west to the Great Fish River in the east, and from the sea in the south to the mountains of the north (the Zuurberg, Swartwatersberg and the Rietberg). It is the region where the winter-rainfall Mediterranean climate of the Western Cape changes to the summerrainfall area of the east and the arid climate of the north. ${ }^{4}$ (see Figure 1) 


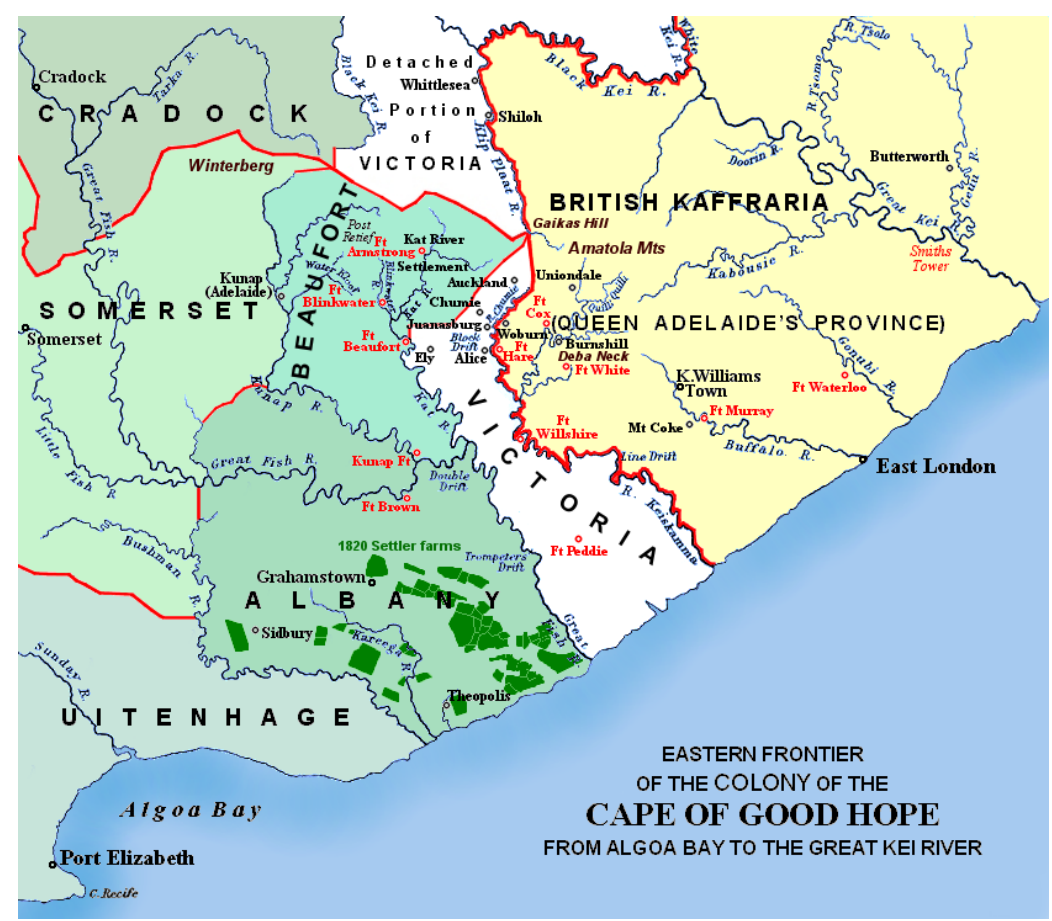

Figure 1: Locations of forts and towns in the Eastern Cape ${ }^{5}$

\section{Setting the scene}

The historical writings covering the British imperial period are fascinating, as they range from the typical British imperial writings, which comprise a combination of propaganda, and an unerring belief that the British were civilising heathen territory and hence an unquestionable force of good, to the liberal writings of post-apartheid South Africa. Writers such as Egerton ${ }^{6}$ typify the Afrikaner viewpoint of the history of the region. Although this article cannot hope to give a comprehensive historical background due to limited space, it aims to give a synoptic and, as far as possible, even-handed historic framework, to gain an understanding of the spatial framework. In brief, the history can be explained as initially a conflict over land and grazing areas as the colonialists expanded eastward and the Xhosa expanded westward, during which there were a number of skirmishes and treaties. Invariably, the treaties only lasted a limited time as the land-hungry colonialists, pressured for expansion, and the population increase and creation of break-away chiefdoms lead to the westward spread of the Xhosa. Both groups were cattle 
farmers and thus cattle theft and conflict over grazing were inevitable. The British, weary of the Dutch colonialists initiated the 1820 Settlers scheme to import British colonialists in order to form a buffer between the Xhosa and the colony. The scheme was fraught with problems as the land portions were too small to be viable, many of the landed gentry who had brought over indentured labour failed, and the labour (many of whom were from the British urban areas) sought employment in the towns and villages as artisans. This state of affairs first led to a class conflict and later to an expansion of the voting franchise.

The British, in terms of one of the treaties with the Xhosa, instituted a socalled spoor law, which allowed the colonialists to enter the Xhosa areas in search of stolen cattle. This was often used as an excuse for cattle raids on the Xhosa areas. As most of the cattle recovered were in fact not stolen, tensions rose, and in 1812, the Xhosa launched an attack on Grahamstown, the capital of the region. Although vastly outnumbered, the colonialist had the advantage of substantial buildings for shelter and canon and rifles against assegai-wielding forces, and thus prevailed.

Over time, the colonialists changed to sheep farming, which helped to reduce stock losses as the Xhosa were not sheep farmers themselves. However, sheep farming requires labour and, increasingly, the colonialists looked to the Xhosa to supply the labour. Tensions were rising. In 1827, Stockenstrom wrote with cynical insight that the colony could not expect a large influx of labourers from Xhosaland as long as that region was "in a state of peace and space aplenty". ${ }^{7}$ In 1809, Collins estimated the strength of the Xhosa nation at about fifty thousand people, scattered over a swathe of territory from the Fish River to the Bashee River. The traveller George Thompson's estimate fifteen years later was one hundred thousand. As the colonial authorities, by sword and pen, extended British domination to cover the whole of Xhosaland and beyond, 'independent' Xhosaland shrunk until by 1855 , according to Governor George Grey, ninety thousand people living west of the Kei were crammed into nine locations totalling only two thousand four hundred and fifty square miles. At the time when the average frontier farm considered sufficient to support one colonial family was over nine square miles in extent, the Xhosa area gave a density of just over thirty-six persons per square mile. Starvation makes a good servant and, as Stockenstrom had predicted, the sheep farmers got the labourers they wanted. ${ }^{8}$

Throughout the early $1820 \mathrm{~s}$, the colonial authorities developed an increasingly aggressive and violent policy towards their neighbours. With correspondence to Cape Town taking nearly two weeks, officials in Grahamstown could easily circumvent colonial regulations and invent cover stories that would 
never be investigated. Somerset needed a powerful justification to bring far larger numbers of Africans into the Eastern Cape. Under the watchful eyes of a few idealistic missionaries and philanthropists it was difficult to launch large-scale labour raids against the chiefdoms on the frontier. People further away from the colony ideally would become the targets. The mythical image of the wicked Zulu King Shaka had already been publicised by illegal British slavers operating in Natal. It had been an effective cover-up. Enhancing this concept, Somerset and his settler henchmen invented the image of 'Fetcani' hordes, set in motion by Shaka's wars of conquest, threatening the colony and driving refugees towards the border. ${ }^{9}$

Throughout 1827 and 1828, the commandant dispatched patrols beyond the colonial frontier and informed Cape Town that he was collecting intelligence on the 'Fetcani' threat and protecting helpless Africans. According to Stapelton, ${ }^{10}$ in reality, these expeditions were capturing people for service on settler farms. Official reports claimed that the labourers were refugees who had fled Shaka and were brought to the colony and 'apprenticed' to Europeans for humanitarian reasons. ${ }^{11}$

Around this time, the emancipation of the slaves and the lack of compensation (largely due to corruption in London) led to the mass exodus of Dutch farmers. The British never truly came to terms with the immigrants from the original settlement and never fully resolved their attitude towards them, which eventually culminated in the South African War at the end of the nineteenth century.

In 1857, in another tragic, but enormously influential twist of history, the Xhosa were induced by a prophecy to slaughter their cattle in a mass sacrifice that was predicted to be followed by a miraculous overthrow of the British. This disastrous act caused widespread starvation and effectively ended Xhosa military resistance for two decades. The cattle killing has been a subject of much debate over the years, with many believing that Sir George Grey incited the visions. In an indepth study, Peires ${ }^{12}$ came to the conclusion that the visions were believed mainly due to the desperate circumstances of the Xhosa people and a widespread lung sickness epidemic of 1855 , which killed as many as half to two thirds of their cattle. From the point of view of this article, the movement broke the back of the Xhosa resistance and vast sections of Xhosa territory were taken over by the British. ${ }^{13}$ 


\section{Settlement establishment and the frontier wars}

Fort Frederick - Algoa Bay

The advantage of Algoa Bay as a landing place for the defence of the country up to Graaff-Reinet was realised during the first British occupation. In the immense frontier district of Graaff-Reinet that had been established by the Dutch in 1786, the burghers (Dutch citizens) were beginning to exercise that freedom of speech and independence of action, which had been spread by the ideals of the French Revolution. The English, arriving in 1795, inherited both the incipient rebellion of the Graaff-Reinet burghers and the warlike raids of both the Boers and the Xhosa on each other.

Major-General Francis Dundas, acting governor of the Cape, placed General Vandeleur in command of 200 dragoons and disciplined Khoikhoi soldiers with orders to establish a military post at Algoa Bay. A prefabricated wooden blockhouse was built in Cape Town and sent round in pieces on board the Camel to Algoa Bay where it arrived in August 1799 with artificers to erect it. It was placed near the beach, so as to command both the fort over the Baakens River and the landing place on the shore. It was capable of housing sixty men and was armed with two threepounders mounted on a flat square roof. ${ }^{14}$

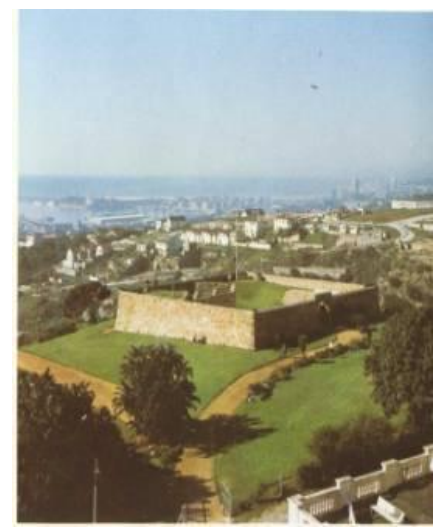

Figure 2: Fort Frederick, Port Elizabeth ${ }^{15}$

On the hill behind the blockhouse, a second blockhouse was erected, surrounded by a massive, square stone redoubt. This was named Fort Frederick in honour of the Duke of York, Commander-in-Chief of the British Army. It is said 
that this was the first piece of substantial and permanent building ever erected in the Eastern Province and it is still in existence today.

The Fort has a commanding view of the whole of Algoa Bay. Its walls are eighty feet (about 24,4 m) long and nine feet (about 2,7 m) high, the wide arched entrance with double gate being situated on the western side. Inside the fort was a powder magazine capable of holding $2000 \mathrm{lbs}(907 \mathrm{~kg})$ of gunpowder and to the left of the entrance was a small guardhouse. Inside the wall was a raised platform for patrol duty and defence. The heavy armament consisted of eight twelve-pounders and the garrison consisted of 350 men, most of whom were housed in barracks near the fort and the first blockhouse. In 1803, the Batavian government took over the Cape by treaty from the British, and in 1804, the new district of Uitenhage was created. And so, the development of a civilian centre around Fort Frederick was for a time delayed, although it apparently remained the military headquarters. ${ }^{16}$

The second British occupation took place in 1806, when Britain's line of communication with the Far East was being threatened by the ambitious plans of the new French regime and the decline of the Batavian government. ${ }^{17}$

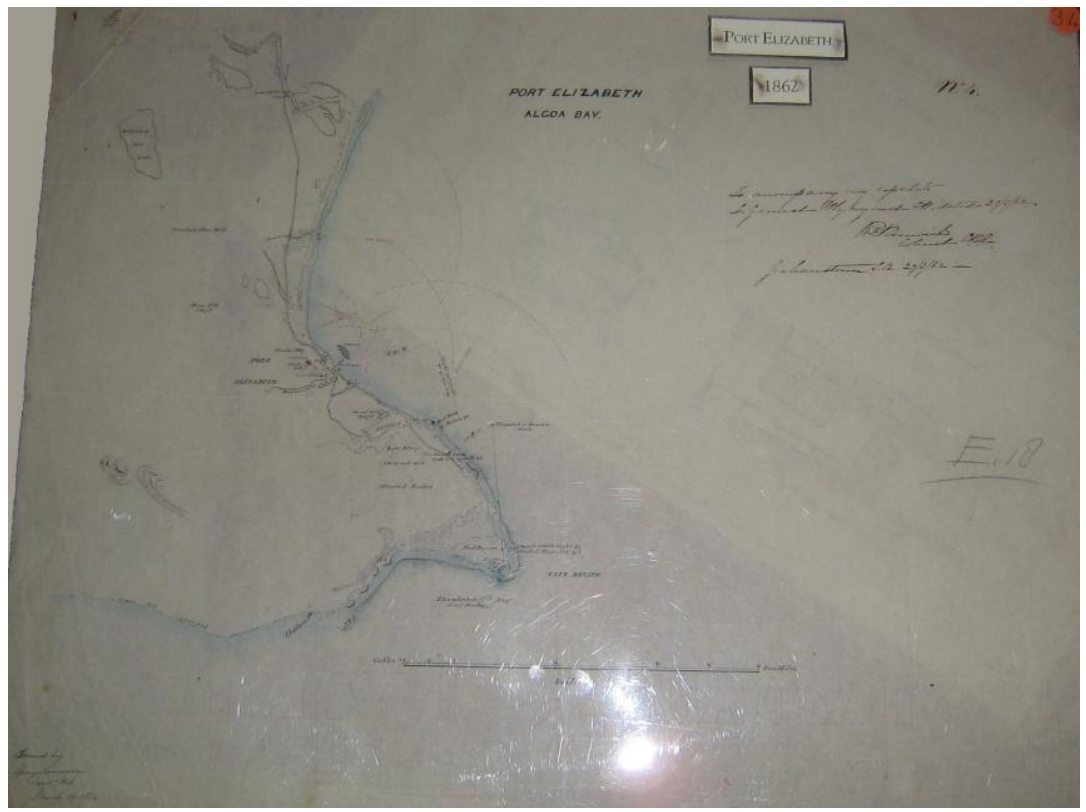

Figure 3: Coastal chart around Algoa Bay 1862 (Port Elizabeth) ${ }^{18}$ 
The British occupation of the eastern frontier illustrates the British approach to colonisation as they expanded via defendable positions, and then consolidated their land gains by settling the area. The fort was as much about the control of the colonial civilian population as it was a statement of power to the Xhosa tribes. Unlike the Dutch settlers who moved into the interior, and who established farms first and then built administrative centres, the British started by creating a fort at a natural harbour manned by military people. The move into the interior was in response to the conflict over land between the settlers and the Xhosa, and was met by the establishment of military headquarters and lines of defensive forts and signal posts. Civilian settlements came later and generally grew around the military posts, for example, Grahamstown and King William's town. The forts formed a front line that was largely defensive by nature. However, in times of battle, troops were deployed from Cape Town making use of the ocean as a means of rapidly moving troops to the area. Overland transportation between the Eastern Frontier and Cape Town was limited, slow and unreliable. The harbour posts were thus a fundamental link in the military strategy.

Figure 3 illustrates the importance of the coastal defences. The map, drawn in 1862, is marked with red semi-circular areas in the bay mapping the lines of sight and distances from the coast of 2500 yards $(2286 \mathrm{~m})$ and 6000 yards $(5486 \mathrm{~m})$. It shows positions of beacons, lighthouses, the breakwater in the harbour and an area marked out for ships riding at anchor. Dangerous reefs and heavy breakers at Cape Recife are depicted and information is also given about the visibility of lights beyond a certain distance out to sea. The plan is signed by Colonel WT Renwick (Royal Engineer) and was drawn to accompany his report to Lieutenant-General Wynyard CB. ${ }^{19}$ Although there is little information concerning the function of this map, there is a possibility that it may have been connected with the coastal survey conducted between 1859 and 1862 by Captain Bailey (Royal Engineer) and a number of Royal Engineer officers. After the completion of the work, the survey party sailed from Algoa Bay to England, only to be shipwrecked on the rocks off Struys Point, an ironic stroke of misfortune. Instruments, drawings and observations were lost "to my infinite regret and annoyance", wrote Captain Bailey. The work thus had to be reassembled. ${ }^{20}$ 
Port Elizabeth

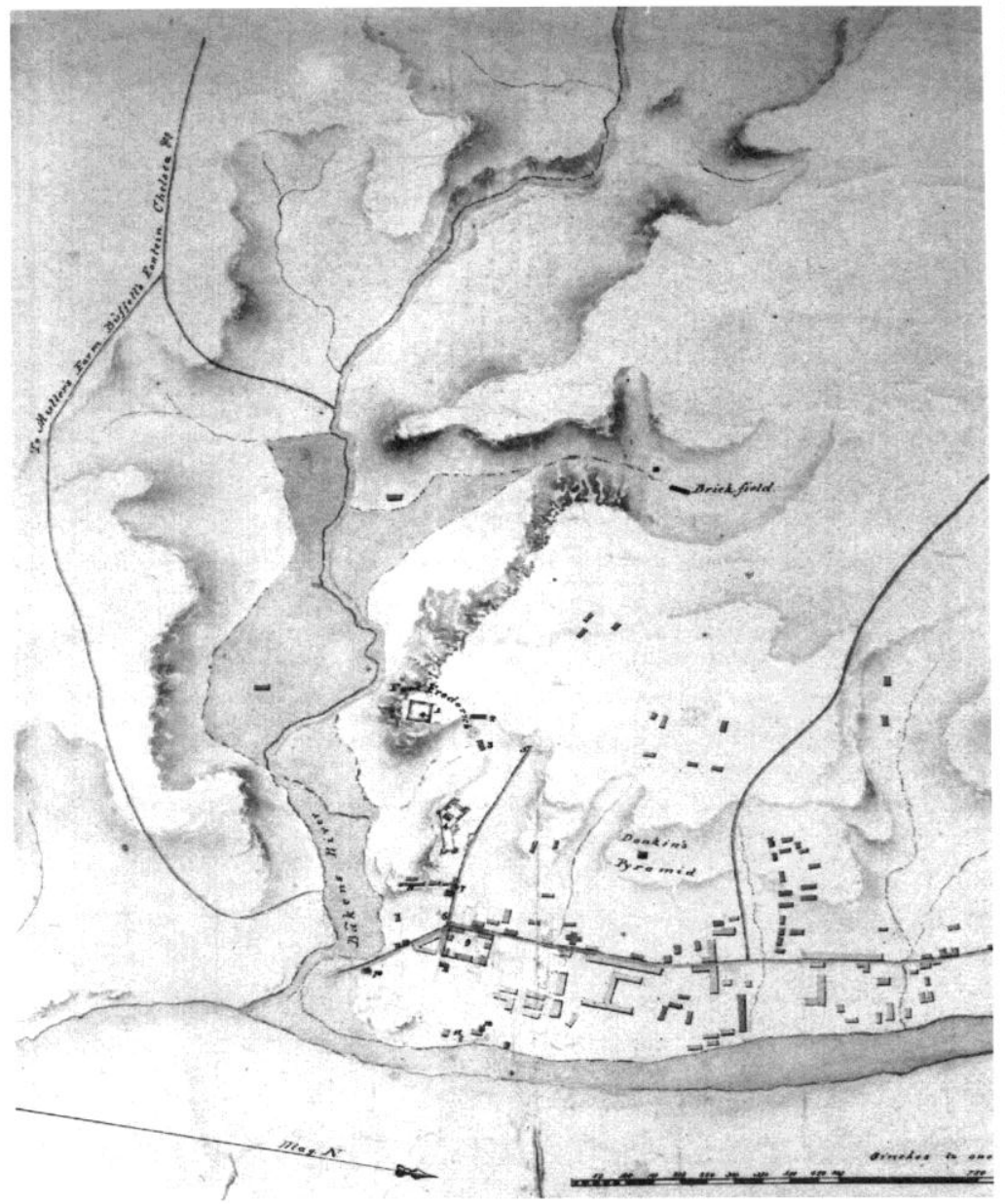

Figure 4: Plan of Port Elizabeth

Figure 4 outlines the relative situation of the existing and proposed military buildings to accompany an estimate report from Lt Col Lewis Comg. R1 Engr to the Inspector General Fortifications dated March $18^{\text {th }} 1837$, signed by HW Piers. Note Donkin's Pyramid. This was a memorial to Elizabeth Donkin, Sir Rufane Donkin's young wife, and was put up in 1821 . Port Elizabeth is named in her honour. ${ }^{21}$ Figure 4 , drawn in 1837 , depicts the early development of the town with the fort in the 
north-west and a small linear town along the coast. The plan was drawn to accompany a report by Lieutenant-Colonel Griffith George Lewis (Royal Engineer) after the Sixth Frontier War (1834-1835) and bears the Royal Engineers' stamp. The plan clearly illustrates the growth of an urban settlement around what was originally a military fort.

\section{The first era of frontier forts}

From the earliest British administration, fortifications were planned. Colonel Graham instituted a series of frontier posts from which patrols could guard the drifts across the Fish River. They were first manned by burghers (civilians) from George and Swellendam, and later by troops. These posts were either rehabilitated farmhouses of wattle and daub, or stone-built shelters enclosed by primitive earthen redoubts. Van Aardt's Post, near the present Longhope siding, was the furthest north and was the recognised crossing place for communication between the colonialists and the Xhosa. Three other posts were (1) the abandoned farm of Conraad Buys, (2) Kranz Drift near the present Pigot Bridge, and (3) Old Kaffir (sic) Drift Post, which was later called Cawood's Post. This was about an hour's ride from Upper Kaffir (sic) Drift Post, established about two years later on the heights overlooking the actual drift, and is not to be confused with Lower Kaffir (sic) Drift, about $3 \mathrm{~km}$ further down the Fish River and about $13 \mathrm{~km}$ from the mouth. ${ }^{22}$

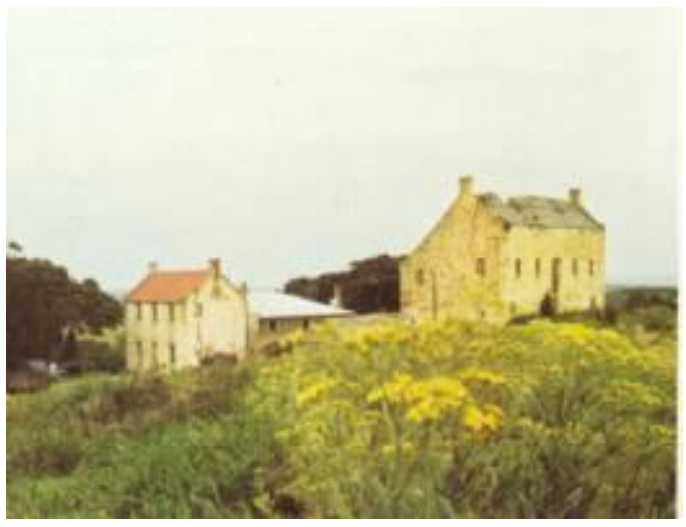

Figure 5: Lombard's Post, buildings and walls forming a hexagonal farmyard. ${ }^{23}$

Colonel Graham recommended that two additional military posts be established. One was to be at Noutoe, a farm $13 \mathrm{~km}$ west of Grahamstown, formerly belonging to the De Lange family, and situated on the road between Bruintjies 
Hooghte and Uitenhage. It was soon abandoned and the site later developed as Table Farm by the 1820 Settler Major TC White. ${ }^{24}$

The other post was established on the loan place (a farm granted on the quitrent basis) of Commandant Piet Lombard, about $48 \mathrm{~km}$ west of the Fish River Mouth. A few kilometres south-west of it, Theopolis, a London Mission Station for Khoikhoi, was founded in 1814. Lombard's Post was a key point in border raids and frontier wars, particularly later on when the area was taken over by settler Benjamin Keeton. In 1835 he erected a fortified farmhouse close to the site of the old post. The stone buildings of the farm, now called Lombard's Post, were placed so as to enclose a spacious hexagonal farmyard and the outer walls were loopholed (see Figure 5). During the war of 1850-51, Lombard's Post saw its last action. Whittles laager was formed near it and the farm buildings were filled with refugees. From it also a patrol was sent out to quell the rebel Khoikhoi at Theopolis. ${ }^{25}$

These early posts were little more than strategic farms manned by local citizens, but were linked to the military intelligence as a series of observation and early warning posts. ${ }^{26}$ One of Colonel Graham's most important contributions was the establishment of a military base and town - Grahamstown, named in his honour in 1812 .

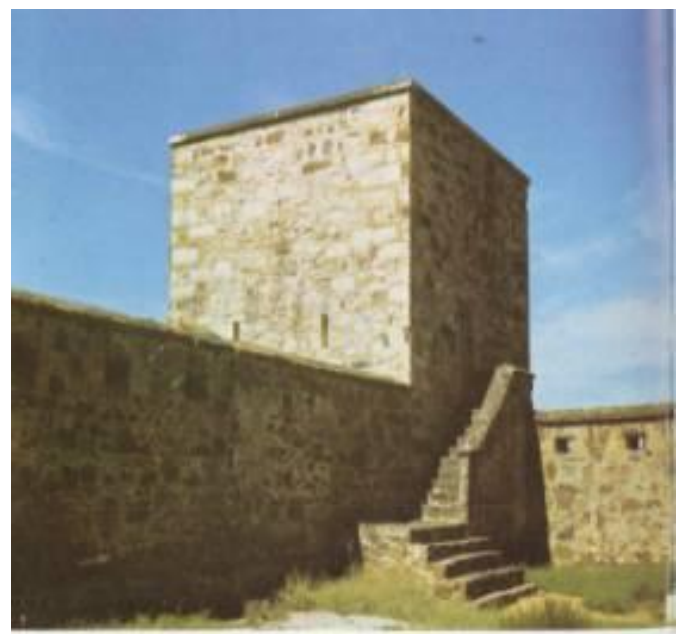

Figure 6: Fort Brown, the gun tower from the parade grounds $\mathrm{s}^{27}$ 


\section{Somerset's observation posts 1814-1819}

Lord Charles Somerset signed a treaty in April 1817 with Ngqika, chief of the Xhosa west of the Kei. Troops on the frontier were warned that they were on duty at the outposts for observation and not for aggression.

"It is his Excellency's wish that these posts should be improved so as to attain that solidity which many of them (constructed of the slightest materials) had not when he inspected them; but this is a service which must not be hurried, and the greatest attention possible should be paid to having the men's Barracks dry and airy..."28

Somerset, in his dispatch on 4 September $1818,{ }^{29}$ also urged the officer commanding on the frontier to hasten with the erection of previously recommended signal stations so that communication with the front line might be improved, depredations reported and culprits apprehended before they vanished across the Fish River. A field officer was to be stationed at Van Aardt's on the left wing and another at one of the Kaffir Drift (sic) posts on the right wing. ${ }^{30}$

A series of outer and inner post lines were created, mostly on farms. The most northerly post was Kruger's Farm, near Slager's Nek (1815), followed by Somerset Farm, Prinsloo's Farm and Roodewal (Cookhouse). Going down the Fish River and about an hour's ride from each other were Van Aardt's, Paul Bester's, De Lange's and Van der Merwe's. Following the eastward meanders of the river were Junction Drift, Wentzel Coetzee's or Espag's (Carlisle Bridge), De Bruin's, Kranz Drift, Koester's and Hermanus Kraal (Fort Brown). It is uncertain whether Double Drift, Committees and Trompetter's Drift were garrisoned at this time, as they were deep in the valley in dense bush. Waai Plaats and Old Kaffir (sic) Drift (Cawood's) on the flats and Upper and Lower Kaffir (sic) Drifts on the river completed the line to the river mouth, with Lombard's Post further west. ${ }^{31}$ 
Bearings and distances between Military Posts

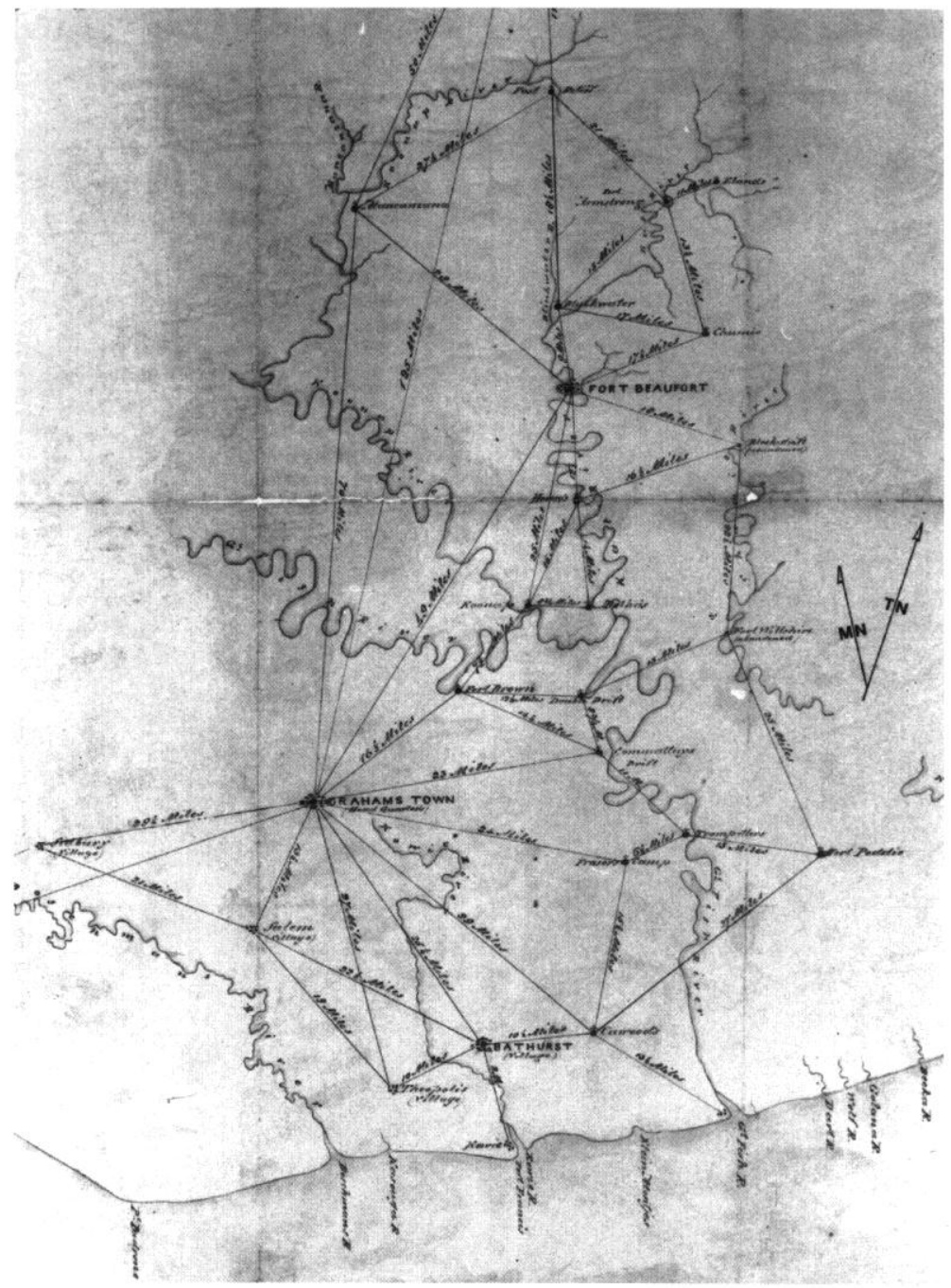

Figure 7: Bearings and distances between military posts, Eastern Frontier. ${ }^{32}$

The inner line of posts was over the Zuurberg from Grahamstown on the road to Uitenhage. These were Assegai Post, Rautenbach's Drift, Vermaak's Farm, 
Sandflats, Nieuwepos, Coerney, Addo Drift and Jacobus Oosthuizen's with Klaas Kraal north-west of Uitenhage (see Figure 7). ${ }^{33}$

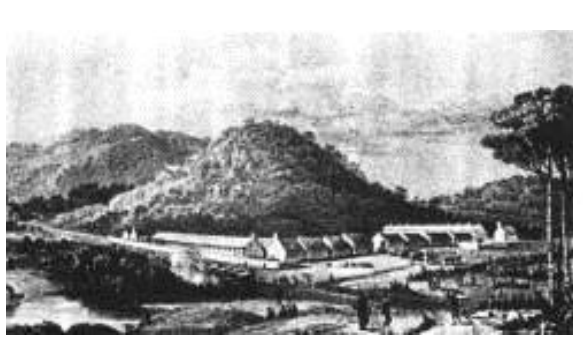

Figure 8: A fair at Fort Willshire Barracks, 1828

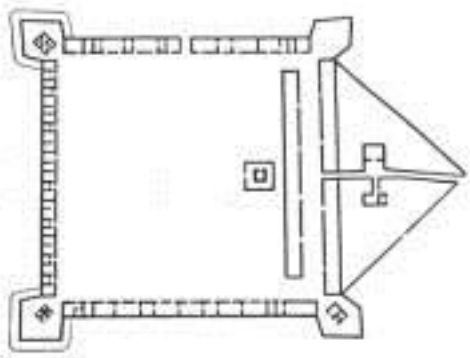

Figure 9: Plan of Fort Willshire Barracks erected in lieu of the first Fort Willshire ${ }^{34}$

Lord Charles Somerset visited the frontier again in October 1819, after the Battle of Grahamstown during which he conferred once more with Ngqika and the assembled chiefs, and the Xhosa agreed to cede a strip of country between the Keiskamma, Tyumie and Great Fish Rivers. This was to be a neutral zone, unoccupied by either colonists or Xhosa and patrolled by troops stationed at two military posts, Fort Willshire and Fort Holloway within the ceded territory. The latter was never built, but the first, Fort Willshire, the most ambitious and most forward military station, was started in November, 1819 (see Figures 8 and 9). ${ }^{35}$ Fort Willshire is actually two fortified barracks about $800 \mathrm{~m}$ apart. The first fort was built on the orders of Somerset, the plan being an irregular pentagon with curtain walls of lengths $2 / 66 \mathrm{~m}$, $2 / 60 \mathrm{~m}$ and $1 / 81 \mathrm{~m}$, with bastions at angles, and ranges of buildings against the curtains and freestanding in the interior. However, Somerset went on leave to England in December 1819, with only one third of the scheme, including all five bastions, being completed by May 1820, after eight months' work. This resulted in the acting governor, General Sir Rufane Donkin, suspending construction and ordering a second fort to be built nearer to the Keiskamma River, which was the eastern border of the 'neutral territory' at the time. Donkin's barracks were sited on lower ground, and consisted of a square of about $180 \mathrm{~m}^{2}$, with four angle bastions and two castle enclosures forming a blunt arrowhead on one side. The arrangement of the interior was similar to Somerset's fort, with the addition of a powder magazine. ${ }^{36}$ Until 1830, the second fort was successful as a trading station on the eastern frontier. ${ }^{37}$ 


\section{The frontier forts 1835-1845: Province of Queen Adelaide}

By 1822, the spread of Xhosa tribes westwards along the foothills of the Amatole Mountains was causing some alarm amongst the colonial authorities. Maqoma and his followers had settled in the valley near the source of the Kat River. In order to check and watch their movements, Colonel Scott erected a blockhouse in 1822 and stationed troops on the north-east bank of the Kat River, naming the site Fort Beaufort in honour of Lord Charles Somerset's family. On the route between Grahamstown and Fort Beaufort, Hermanus Kraal grew in significance, and Tomlinson's Post, near the juncture of the Fish and Koonap Rivers was established.

Towards the end of 1834 , events moved swiftly to a climax, with over 12000 Xhosa invading the colony, in what was later to become known as the 'Sixth Frontier War'. Fort Willshire was abandoned, and refugees poured into Grahamstown. Colonel Harry Smith, after an epic ride from Cape Town, arrived to take command. He directed a three-pronged attack from Committees Drift, Trompetter's Drift and Upper Kaffir (sic) Drift. The attack was pushed past the Keiskamma River and troops eventually crossed the Kei River. Governor Sir Benjamin D'Urban joined in the final conduct of the campaign, proclaimed the new boundary of the colony to be the Kei River, and named the new area Province of Queen Adelaide. ${ }^{38}$ The first measure Governor D'Urban took for the protection of the new province was to erect Fort Warden, on the west bank of the Kei, overlooking the river crossing, about fifteen miles $(24 \mathrm{~km})$ downstream from the present rail bridge. Subsequent to this, Fort Waterloo was established as a temporary observation post on the road east of the Gonubie River.

\section{Forts and signal towers of the Lewis Line, 1837-1846}

After the war of 1835, the planning of the system of frontier defence fell on three men, Lieutenant-Colonel Griffith George Lewis, Commanding Royal Engineer (1784-1850), Captain WFD Jervois (Royal Engineer), and a civilian employee of the War Office, Henry L Hall. ${ }^{39}$ Lewis was the commanding Royal Engineer in the colony at the time. He repeatedly expressed his frustration at the tardiness of the British government in allocating funds for the effective defence of the frontier districts. He wrote extensively on frontier defence policy, and complained that for years after the close of the war no clear decisions had been taken on how funds were to be utilised. ${ }^{40}$ Jervois is known to have worked on Forts Peddie, Trompetter's Drift, Double Drift and Brown. Jervois' next appointment was in Alderney in the Channel Islands, where he spent the 1850 s designing and supervising the 
construction of a whole series of fortifications (it was he who built the Solent forts). ${ }^{41}$

It bears mention that, at the same time that a number of rather flimsy forts were being built in the new Province of Queen Adelaide (most of them to be abandoned within twelve months), Lieutenant Colonel Lewis, Commanding Officer of the Royal Engineers at the Cape, drew up the Lewis Scheme (referred to as the Lewis Line) for a series of strongly fortified barracks at Trompetter's Drift, Double Drift, Fort Brown, Botha's Post, Post Retief along the Fish River and Fort Armstrong. The six forts of the Lewis Line were rectangular fortified barracks for infantry and cavalry, each surrounded by a loop-holed wall three meters high. Officer's and men's quarters, commissariat stores, stables, a cookhouse, a bakery, etc, were arranged around the inside of the enclosure and many of the forts incorporated a two-storey piquet or gun tower projecting from one corner, on the flat roof on which was mounted a light 6-pounder or a 4.5 or 5.5-inch howitzer. Some of the forts also exhibited a similar projection at the corner diagonally opposite the gun tower, giving flanking fire along the other two walls. Several of these forts were placed to defend 'drifts' or fords over the Fish River, which marked the border at the time. $^{42}$

The imperial government also approved of Lewis's scheme for 'signal towers', and new roads and bridges to improve communications between these forts and the headquarters at Grahamstown where new barracks were to be built on the old Drostdy Ground (Gledhill, 2008). Circa 1843 Henry Hall compiled a map which was later copied by Private John Reid (Sapper). It showed the bearings of principal military posts and remarkable peaks visible from proposed sites of signal towers in the Fish River region (see Figure 7). ${ }^{43}$

In 1837, Lewis recommended that communications with Fort Beaufort and Fort Peddie be improved by a series of signal towers based on Fort Selwyn in Grahamstown. The system was devised by Lewis and executed by Jervois and Hall between 1837 and $1842 .{ }^{44}$ The survey to establish suitable points on which to erect the stations was done by Henry Hall, stationed in the Eastern Cape in the period 1842-1858. The stone-built towers were about 30 metres high. These towers had only one entrance to the first floor, and were provided with ladders which could be drawn up before the door was closed. A staircase led to the flat roof of the tower on which was mounted a semaphore, a type of signalling mast first developed by Claude Chappe, during the French Revolution. 
The mast was composed of a 'regulator', pivoted at its centre so that it could rotate and also slide up and down. At either end of the regulator were indicator arms which could each be placed in seven different positions. In practice, only 196 combinations of positions were used, although there was the possibility of more.

The Fort Beaufort Line of signal stations went from Governor's Kop to Grass Kop, Botha's Post, Dan's Hooghte and Fort Beaufort. When war with the Xhosa broke out in 1846, all the towers on this line had been completed and equipped with semaphore masts: A projected extension to Zwart Kei Post was never carried out. Henry Hall, when testing the section between Dans Hooghte and Fort Beaufort, found that the signals made to Fort Beaufort from Dans Hooghte could not easily be read although his signals from Dan's Hooghte were clearly visible at Fort Beaufort. Unless the towers were placed against the skyline, it was difficult and sometimes impossible to read the signals, furthermore the telescopes supplied were not sufficiently powerful. So the signalling system was less than successful. The signal towers were in fact of very little use, for the signals were difficult to decipher, the up-keep of the garrisons expensive and water supply at the towers was always a problem. Henry Hall later recorded, "Within one month of the outbreak of war (1846) all these towers were in ruins, abandoned by us or burnt by the enemy." 45

Prior to these signal towers there had been a certain amount of signalling in the Table Bay and False Bay areas, but nothing as substantial as the eastern frontier semaphore system existed elsewhere in South Africa, and possibly in the British Empire. ${ }^{46}$ Probably only in Britain itself was the system as extensive as here. In the Cape Monthly Magazine of November 1859, Hall wrote a description of the system. There were two lines of communication, one from Grahamstown (Fort Selwyn) through Governor's Kop tower, Gras Kop, Botha's Post, Dans Hooghte to Fort Beaufort, the other from Grahamstown again through Governor's Kop tower to Fraser's Camp, Piet Appel's tower and Fort Peddie. A third line down to Bathurst from Fraser's Camp was never constructed. The entire system cost five thousand pounds. The cost of each tower was five hundred pounds. Each was manned by a sergeant and five men. ${ }^{47}$

After the Sixth Frontier War of 1834-1835, the eastern frontier was considerably strengthened by increasing the number of troops, military engineers and forts. $^{48}$ 


\section{The Seventh Frontier War, 1846-1847}

The initial disasters of the war which commenced in March 1847 were severe. Elands Post, at the foot of the Katberg, was abandoned. A strong punitive force under Colonel Somerset, which had pushed across the border of the colony to Burn's Hill near Fort Cox, had to retreat to Block Drift, but at the Keiskamma River crossing, another heavy attack resulted in the loss of half of the 125 ox wagons carrying military stores. Fort Peddie was overwhelmed. In Lower Albany, Cuylerville, Bathurst and the fortified farmhouses were besieged. Refugees flocked to Grahamstown where the streets were barricaded. Eventually, Fort Peddie was relieved via Committees Drift and Trompetter's Drift and the Battle of the Gwanga ended in a resounding victory for the colonial forces.

A temporary earthen fort was built by seamen of HMS President on the west bank at the mouth of the Fish River as a base for troops crossing into the war zone. It was named after Admiral Dacres. Reinforcements also came by sea from Cape Town, and some were landed at Waterloo Bay, immediately east of the river mouth. The campaign was pushed eastwards, and an advanced base was set up at old Fort Warden for the final push across the Kei River.

The new governor, Sir Harry Smith, arrived in December 1847. On landing, he issued two proclamations: the first extended the boundary of the colony to the Keiskamma River, thus re-incorporating the old Ceded Territory. The chief town was to be Alice and Fort Hare was built to protect it.

By the second proclamation, the territory between the Keiskamma and Kei Rivers became British Kaffraria (sic), which was virtually the former Province of Queen Adelaide. Re-occupation of Sir Benjamin Durban's old forts started immediately. Fort Hill was in ruins, but King William's Town was re-built as headquarters for the troops in British Kaffraria (sic). Colonel Evelyn wrote of the Rifle Brigade

They built a town, they built a barracks, they built houses for their officers, some of 'wattle and daub', some of bricks, and roofed with various materials. They also made an aqueduct some 3 or 4 miles long to supply the camp with water and for irrigation. When we left they had more than half built permanent barracks of stone ..."49

Fort Glamorgan was established on the west bank at the mouth of the Buffalo River and on January 14, 1848 Sir Harry Smith named the new port East London. 


\section{The Eight Frontier War, 1850-1853}

The defection of the Khoikhoi began in the Kat River Valley and spread to Theopolis and Whittlesea. Hermanus, the Kat River leader, was killed early in January 1851 when leading an assault on Fort Beaufort. William Uithaalder, a Cape Corps pensioner assumed command and with augmented forces led an attack on Fort Armstrong. ${ }^{50}$ The colonialists managed to escape and the fort became Uithaalder's stronghold and storehouse for plunder. In February of that year, a force assembled at Post Retief consisting of 200 English, 400 Burghers, 200 Fingoes and volunteers from Grahamstown under Commandant Currie. They proceeded to Fort Armstrong where they met with stubborn resistance. Reinforcements arrived under Colonel Somerset from Fort Hare after which a number of 'rebels' were successfully repulsed. The attack at the Fort was pressed home with two howitzers, the walls were breached and 400 women and children were taken into custody.

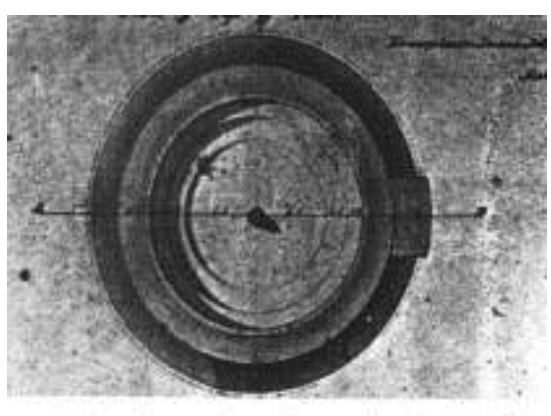

Figure 10: Martello Tower, Keiskammahoek

Emplacement for rotating canon at top of tower

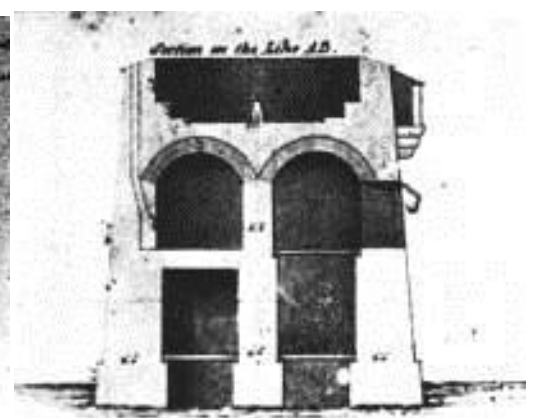

Figure 11: Sectional view showing basement magazine, left and store room, right: barrack floor with entry port; gun emplacement on top ${ }^{51}$

Sir George Cathcart took office as governor in March 1852, and by August 1852, a large force had been assembled for a concerted drive across the Kei. Sandile fled and Kreli, chief of the Ngqika called for peace, which was proclaimed in March 1853. In response, Cathcart introduced his blockhouse policy to police the frontier, which called for the erection of eight towers in the area between the Keiskamma and the Kei. Only one of these was ever built, Castle Eyre, called after Colonel Eyre of the 75th Regiment, which was erected on the outskirts of Keiskammahoek. The 
tower of two storeys was fifteen square foot (4,5 square meters), with a flat roof which provided emplacement for a swivel gun. ${ }^{52}$ (see Figures 10 and 11)

\section{British colonial policy}

In his book Of planting and planning: The making of British colonial cities, Robert Home ${ }^{53}$ explains the evolution of a British colonial spatial development strategy. The strategy evolved over a period of two centuries, ending in the 1840s. During this period, England established new settler colonies in Ireland, the New World and the Antipodes, in accordance with a centrally devised scheme. In the 1670s, Lord Shaftesbury formulated (or at least refined) a scheme he called the 'Grand Modell'. Its aims included commercial gain, strategic manoeuvring in the game of international geopolitics and, later, the removal of unwanted social groups (political or religious dissenters, debtors and the unemployed). In the nineteenth century, emigration was widely deployed as a means of reducing population pressure at home. ${ }^{54}$

The main components of the model can be summarised as:

Policy of deliberate urbanisation

Towns were seen as the centres of trade and defence and a civilising influence. The unsatisfactory alternative to such a policy, as perceived by Shaftesbury, was that settlers "will expose themselves to the inconvenience and barbarism" of "straggling and distant habitations" in the countryside. ${ }^{55}$ The policy was intended to avert the danger of a rejection of central authority, as occurred in Bacon's rebellion in Virginia in 1676. Although it has been argued that colonial development was primarily interested in primary resources such as minerals and agriculture, which are rural, the method of colonisation was unmistakably urban in focus, nature and form.

Allocation of town and country land rights

The policy of deliberate urbanisation was to be secured through land settlement, by structuring a symbiotic relationship between town and country. Under the Shaftesbury 'Grand Modell', land was allocated to the settlers in both town and country lots (and sometimes suburban or garden plots as well). Thus, a land owner would have both types of property on which both to live and make a living. ${ }^{56}$ 
Town planning in advance of settlement

The town site was laid out in advance of occupation, according to a prepared plan. This assumed that a sufficient number of colonists were available to begin a settlement, a figure which was set at forty families in Ulster and fifty in New Hampshire. Such advanced planning was intended, in the words of an observer of the Carolina Colony in 1680, to avoid the "undecent and incommodious irregularities which other Inglish Collonies are fallen unto for want of ane early care in laying out the townes", 57

Wide streets in geometric form

The physical form of the colonial planned town was a rectilinear or grid-iron layout of wide streets, embodying classical ideals of symmetry, order and proportion i.e. "The ultimate symbol of the imposition of human order on the wilderness". 58

Public squares

The centrepiece of this regular grid of wide, straight streets was the square reserved for public use, often framed by four or more satellite squares.

Standard-sized, rectangular plots

The street blocks of the colonial grid were subdivided into large, rectangular town plots. Plot dimensions varied. Plot frontages of fifty feet $(15,2 \mathrm{~m})$ wide or more, i.e. two or three times those found in British towns of the period were available. The colonial plan actively discouraged continuous built-up frontages, partly reflecting the ready supply of land, but more so as a response to the two great dangers of urban life at the time - fire and disease. Thus did London's Great Plague of 1665 and Great Fire of 1666 (which both Shaftesbury and Penn lived through) leave their mark on colonial planning. ${ }^{59}$ In Philadelphia, according to Penn,

... every house be placed, if the person pleases, in the middle of its plot, as to the breadth way of it, so that there may be ground on each side for gardens, or orchards, or fields, that it may be a green country town, which will never be burnt and always be wholesome. ${ }^{60}$ 
Public land reservation

Land was to be reserved for public purposes and as a source of public revenue in the form of houses for public affairs, meeting houses, assembly or state houses, market houses, school houses, etc. ${ }^{61}$

Green belts

A green belt, or physical separation of town and country, first appeared in colonial towns (circa 1600s) and was later adopted in England from the 1920s onwards. These areas were town lands for common sheep pasturing. ${ }^{62}$

Strategic settlement establishment process

The idea of a 'model settlement' emerged early on in Britain's overseas expansion. Despite their divergent national origins, the various groups involved in the colonisation process each acted with some degree of international cohesion. The politicians, most of whom never visited the colonies, drew the boundaries. The soldiers carried out the conquests and frequently chose the ports from which to control the population. The military often formed the first colonial governments and coercion was an essential part of the maintenance of colonial administration. ${ }^{63}$ "Indeed the demarcation between soldier and administrator in the colonies was rarely defined. The administrators determined the pattern of urban settlement by selecting the administrative posts and deciding upon the nature of the administrative regime" ${ }^{64}$. This bias towards functional administration, and the use of military personnel to implement it, had a profound impact on the spatial development of South Africa - it was ordered, spacious, functional and 'logical' (from a colonial point of view).

\section{Conclusions}

A study of strategic defence strategies of the era is informative, as the approach adopted in the Eastern Cape, was not only in line with British policy at the time, but was also very avant-garde, illustrating the flow of information between Britain and its colonies. In short, the British military not only theorised about defence, they also tested it regularly in the field, and the two-way flow of information lead to a pragmatic re-evaluation and refining of strategies. British colonisation illustrates the importance of a seamless flow of information throughout an empire, as much of the British dominance can be ascribed to the flowering of the 
sciences and the maintenance of the intellectual advantage so established through communication.

Equally important to note is the British keenness to try new ideas and their readiness to abandon those which did not work, such as the Lewis Line signals. The approach was pragmatic and, crucially, theory was tested in practice. It is interesting that, even though they were defending the frontier against an enemy armed with assegais and sticks, the British did not revert to fortified towns. Instead they created defendable lines of signal towers and forts as observation posts, an early warning system and a visual deterrent. One reason for this was that they were trying to defend a vast marginal farming frontier, rather than towns serviced by smaller more fertile intensive agricultural areas such as in Europe.

The Eastern Cape frontier illustrates most clearly the British colonial policy of exerting control over an area by means of strategic settlement expansion. All of the settlements in the Eastern Cape had a very strong military component, and were very often surveyed and largely constructed by military people - most notably the Royal Engineers. The British tried to subdue the turbulent frontier by settling British immigrants in the area, by establishing towns, and when that failed, by creating military defence lines by means of a series of forts, military garrisons and signal towers. At this stage, the British policy was not to wage war and exterminate the threat, but to slowly encroach into tribal areas and cement these gains by settling the area and creating towns and infrastructure in order to manage and maintain the area. Far from wanting to exterminate the Xhosa, the British were intent on forcing them into a servile state to provide a labour force for the colony. Military personnel were not only used to create this infrastructure and to prepare the layouts of the towns, but in the case of Grahamstown and King William's Town, were also the main occupants of the towns.

\section{Endnotes}

1 Christopher, AJ, Southern Africa. Folkestone, England: Dawson Archon Books, 1976, 51.

${ }^{2}$ Le Cordeur, BA, The Politics of Eastern Cape Separatism 1820-1854, Cape Town: Oxford University Press, 1981.

${ }^{3}$ De Klerk, W, The Puritanns in Africa: A Story of the Afrikanerdom, London: Rex Collings, 1975.

${ }^{4}$ Maclennan, B, A proper degree of terror: John Graham and the Cape Eastern frontier. Johannesburg: Raven Press, 1986, 43. 
${ }^{5}$ See the article of Mellet, PT, "The Black Roots of the Vine in Franschhoek and Environs" Available at the webpage of Cape Slavery Heritage. < $\underline{\text { http://cape- }}$ slavery-

heritage.iblog.co.za/?s=The+Black+Roots+of+the+Vine+in+Franschhoek+a nd+Environs> Accessed 26 June 2012

${ }^{6}$ Egerton, HE, A short history of British Colonial Policy 1606-1909. Revised by AP Newton. London: Methuen, 1945.

${ }^{7}$ Le Cordeur op. cit., p. 228.

${ }^{8}$ Ibid., pp. $228-229$.

9 Stapleton, TJ, Maqoma: Xhosa resistance to colonial advance 1798-1873. ${ }^{10}$ Ibid. Johannesburg: Jonathan Ball, 1994, 49.

${ }^{11}$ Peires, JB, The Dead will Arise: Nongqawuse and the Great Xhosa Cattle Killing Movement of 1856-7, Johannesburg: Raven Press, 1989; Gledhill, E, Forts of Frontier Country, Compiled for the Grahamstown Historical Society, 2008. Photographs by Rex and Barbara Reynolds. Published by the 1820 Settlers National Monument Foundation, Grahamstown.

${ }^{12}$ Peires, JB, op. cit.

${ }^{13}$ For further reading on the history of the region please refer to Robson, LG. "The Royal Engineers and settlement planning in the Cape Colony 1806-1872: Approach, methodology and impact". PhD thesis. University of Pretoria, 2011; Peires, JB. op.cit.; Stapleton, TJ. op. cit.; Le Cordeur, BA. The politics of Eastern Cape separatism 1820-1854, op. cit.; Le Cordeur, BA (ed). Journal of Charles Lennox Stretch. Cape Town: Maskew Miller Longman, 1988.

${ }^{14}$ KAB Map M1/2004 . KAB Map M1/2249.

${ }^{15}$ Gledhill, E. Forts of frontier country. Grahamstown: The 1820 Settlers National Monument Foundation, 2008.

16 SAB X6/52/39 Historical Monuments Commission. Gledhill op. cit.; Garson (1992) op. cit. p. 7. Garson (1992) op. cit. p. 77. KAB 1/413 Cape Archives Report of the Goedetic Survey - Royal Engineers 1892- 1897.

${ }^{17}$ Gledhill op. cit.

${ }^{18}$ Photographed by author from the original Royal Engineer's Collection, William Cullen Library, University of the Witwatersrand.

${ }^{19}$ Garson op. cit., p. 77.

${ }^{20} \mathrm{KAB}$ GH 1/19 Papers received from Secretary of State, London Appointment of Colonel Graham as Commandant at Simons Town, 1816. Gledhill (2008) op. cit.

${ }^{21}$ Garson, op. cit. p. 25.; KAB Jeffreys Collection 1894. Photo Donkin Memorial.

${ }^{22}$ Gledhill op. cit.

${ }^{23}$ The buildings pictured are from the post 1820 Settler era. Ibid.

${ }^{24}$ Gledhill op. cit. ; KAB GH 23/6, 1818 
${ }^{25}$ Gledhill op. cit. Tomlinson, R, Three centuries of fortifications in South Africa 1652 to 1958, The Fortress Study Group, FORT 34, 2006.

${ }^{26} \mathrm{KAB}$ GH 23/4 op. cit.

${ }^{27}$ Gledhill op. cit.

${ }^{28}$ KAB GH 23/5, 1814, Papers despatched to Secretary of State, London, Lord Charles Somerset reporting his arrival at the Cape.

${ }^{29} \mathrm{KAB}$ GH 23/6, 1818.

${ }^{30}$ Thompson, L, A History of South Africa, Cape Town: Jonathan Ball Publishers, 2006 (second edition); KAB Accession A1619 1820-1880 Dr van Heerden Papers, Letters by Sir Rufane Donkin 1820, VAB AMPT PUBS IBB, communications between colonial Department and Lieut-General Sir Rufane Donkin, 1827.

${ }^{31}$ Gledhill op. cit.; Garson op. cit.; Thompson op. cit.

32 The 1844-1845 bearings and distances between military posts, Eastern Frontier. The sketch shows relative bearings and distances per wagon route between the different military posts on the Eastern Frontier of the Cape of Good Hope. Garson op. cit., p. 31.

${ }^{33}$ KAB GH 23/4 (1814), 23/5 (1814), 23/6 (1818), 23/7 (1825), Papers despatched to the Secretary of State, London, from Lord Charles Somerset; KAB VC542, Letter from James Barry, 1825.

${ }^{34}$ Gledhill op. cit.

${ }^{35}$ Meredith, M. The state of Africa: A history of fifty years of independence. $2^{\text {nd }}$ ed. Johannesburg: Jonathan Ball, 2006 ; Thompson op. cit.

36 KAB Accession A1619 1820-1880, Dr Van Heerden Papers, Letters by Sir Rufane Donkin 1820, VAB AMPT PUBS IBB, communications between colonial Department and Lieutenant-General Sir Rufane Donkin, 1827.

37 Tomlinson op. cit.

${ }^{38}$ Benyon op. cit. pp. 71; 73. Garson op. cit. p. 33; Cape Quarterly Review, July 1882: 714-716.

39 Benyon, J. "Trompetter's drift and the signal towers". In McDaniel, JB, Holleman, W \& Jacot Guillarmod, A (eds), Grahamstown and its environs, $2^{\text {nd }}$ ed, Grahamstown: Rhodes University Printing Unit, 1985, 70-74.

${ }^{40}$ Benyon op. cit. pp. $73-74$.

${ }^{41}$ Tomlison op. cit., pp. 9-10.

${ }^{42}$ Kirby, op. cit.; Gledhill op. cit.; Home, R, Of Planting and Planning: the Making of British Colonial Cities; London: E and FN Spon, 1997, 8-29.

${ }^{43}$ Garson op. cit., p. 33.

${ }^{44}$ Benyon op. cit., p. 73.

${ }^{45}$ Reps in Home op. cit., pp. 11-13.

${ }^{46}$ Benyon op. cit., p. 73.

${ }^{47}$ Ibid., p. 74.

${ }^{48}$ Kirby, PR. "South Africa's first telegraph". Africana Notes and News 14. 1960. 123-129.

${ }^{49}$ Garson op. cit., p. 79. 
50 The Cape Corps started as the first mixed race unit the Corps Bastaard Hottentoten (Dutch for "Corps of Bastard Hottentots"), which was organised in 1781 by the Dutch colonial administration of the time. The British formed The Cape Regiment in October 1806. Headquartered in Cape Town, it was organised as a typical colonial unit with British officers and Coloured (sic) other ranks. In later years, the Regiment also had a troop of light cavalry added. On 24 September 1817, the Regiment was reduced in size to two small units of about 200 men for the defence of the Cape Colony's eastern frontier. The two units were named the Cape Cavalry (consisting of one troop of dragoons) and the Cape Light Infantry. In 1820, these two units were again combined under a unified command and renamed the Cape Corps.

${ }^{51}$ Gledhill op. cit.

${ }^{52}$ Kirby op. cit.

53 Home, R. Of planting and planning: The making of British colonial cities. London: Eand FN Spon, 1997, 8-29.

${ }^{54}$ Ibid., p. 8.

${ }^{5}$ Ibid., p. 9.

${ }^{56}$ Ibid., p. 10.

${ }^{57}$ Ibid., p. 11.

58 Ibid.

${ }^{59}$ Ibid., p. 13.

${ }^{60}$ Ibid.

${ }^{61}$ Ibid., p. 14.

62 Ibid.

63 Christopher, AJ. Early settlement and cadastral framework: Salisbury - a geographical survey of the capital of Rhodesia. London: Hodder and Stoughton, 1977.

${ }^{64}$ Ibid., p. 3. 